\title{
Bartın İlinde Yetiştirilen Fındığın (Corylus avellana L.) Zurufunun (Yeşil Yapraklı Kabuk) Antioksidan Özel- liklerinin İncelenmesi
}

\author{
Investigation on the Antioxidant Properties of Husks (Green Leafy Covers) of \\ Hazelnut (Corylus avellana L.) Grown in Bartin
}

\section{Mehmet KURTÇA}

Selçuk Üniversitesi, Fen Fakültesi, Kimya Bölümü, KONYA

email: mehmet.kurtca@selcuk.edu.tr

0000-0003-3432-3871

\section{ÖZET}

Antioksidanlar insan vücudunda biriken serbest radikalleri temizleyerek, vücudun çeşitli hastalıklardan korunmasını sağlayan önemli yapılardır. Vücutta enzim, hormon ve protein olarak birçok antioksidan mevcuttur. Bunların dışında doğal olarak birçok besinde bulunan vitaminler, tanenler, flavonoidler, fenolik bileşikler gibi çok sayıda antioksidan madde de vardır. Fındık antioksidan madde içeren besinlerin başında gelmektedir. Ülkemizde bolca yetişen ve ülkemiz ekonomisine katkısı olan bir bitkidir. Fındık hasadı ve işlenmesi sırasında zuruf, kabuk, iç zar gibi yan ürünler ortaya çımmakta fakat bu ürünlerden çok fazla ekonomik katkı sağlanamamaktadır. Bu çalışma fındık yan ürünü olan zurufun yüksek antioksidan özelliğe sahip olduğunu ve sanayide farklı alanlarda kullanılarak ekonomiye katkı sağlanabileceğini göstermek amacıyla yapılmıştır. Bu amaç doğrultusunda Bartın ilinde yetiştirilen tombul findık (Corylus avellana L.) türünün zurufları taze olarak toplanmış, su, aseton, su-aseton ve etanol gibi farklı çözücülerle ekstresi elde edilmiştir. Elde edilen ekstrelerin toplam fenolik, ve flavonoid miktarı, DPPH serbest radikal süpürücü aktivite, ABTS katyon radikal giderim aktivitesi ve Bakır (II) indirgeme antioksidan kapasitesi tayinlerine (CUPRAC) bakılmıştır. Sonuçlar incelendiğinde findık zurufunun yüksek antioksidan özelliğe sahip olduğu görülmüştür. Ayrıca su-aseton ekstresinin, diğer ekstrelere göre toplam fenolik miktar $(273.56 \pm 10.12 \mathrm{mg} / \mathrm{g}$ ekstre), DPPH $(18.74 \pm 0.87 \mu \mathrm{g} / \mathrm{ml})$, ABTS $(4.78 \pm 0.56 \mu \mathrm{g} / \mathrm{ml})$ ve CUPRAC 
$(8.74 \pm 2.13 \mu \mathrm{g} / \mathrm{ml})$ aktivitelerinde en iyi sonucu verdiği tespit edilmiştir.

Anahtar Kelimeler: Fındık, zuruf, yeşil yapraklı kabuk, antioksidan, DPPH, ABTS, CUPRAC, toplam fenolik miktar

\section{ABSTRACT}

Antioxidants are important structures that protect the body from various diseases by clearing the free radicals accumulated in the human body. There are many antioxidants in the body like enzymes, hormones, and proteins. Apart from these, there are many antioxidant substances such as vitamins, tannins, phenolic acids, flavonoids, which are naturally found in many foods. Hazelnuts are one of the foods that contain antioxidants. It is a plant that grows in abundance in our country and contributes to the country's economy. During the hazelnut harvest and processing, it also occurs by-products such as husk, shell, and skin and there is not much economic contribution from these products. This study was carried out to show that hazelnut husks which are a by-product of hazelnut also have high antioxidant properties and can be used in different fields in the industry to contribute to the economy. For this purpose, husks of the plump hazelnut (Corylus avellana L.) species grown in Bartın were freshly collected and extracted with different solvents such as water, water-acetone, acetone, and ethanol. The obtained extract of total phenolics and flavonoid amount, DPPH free radical scavenging activity, ABTS cation radical removal activity, and copper (II) reducing the determination of antioxidant capacity (CUPRAC) were measured. When the results were examined, it was seen that hazelnut husks had high antioxidant properties. In addition, the total phenolic amount $(273.56 \pm 10.12 \mathrm{mg} / \mathrm{g}$ extract $), \mathrm{DPPH}$ $(18.74 \pm 0.87 \mu \mathrm{g} / \mathrm{ml})$, ABTS $(4.78 \pm 0.56 \mu \mathrm{g} / \mathrm{ml})$ and CUPRAC $(8.74 \pm 2.13 \mu \mathrm{g} / \mathrm{ml})$ activities of water-acetone extract compared to other extracts has been determined to give the best results.

Keywords: Hazelnut, husk, green leafy cover, antioxidant, DPPH, ABTS, CUPRAC, total phenolic amounts.

\section{GİRİŞ}

İnsan vücudunda zaman zaman metabolik reaksiyonlar sırasında UV ışınları, radyasyon, stres, sigara, alkol, ilaçlar gibi dış nedenlere bağlı olarak son derece aktif yapılar olan serbest radikaller ve reaktif oksijen türleri oluşabilir. Antioksidanlar, vücutta bulunan oksitlenme özelliğine sahip maddelerin bu aktif yapılar tarafindan oksidasyonunu önlemekte veya geciktirmektedir. Antioksidanların bu özelliği sayesinde kanser, kalp hastalıkları, diyabet, akciğer hastalıkları, nörodejeneratif hastalıklar gibi birçok hastalığın ve hızlı yaşlanmanın önüne geçilebilmektedir (Cornelli, 2009; Matsingou ve ark., 2000; Yılmaz, 2010). Vücutta enzim, hormon ve protein olarak birçok antioksidan görev yapmakta ve bu antioksidanlarla serbest radikaller arasında bir denge bulunmaktadır. Fakat yaşlanmayla birlikte vücuttaki bu denge bozulur. Bu durumda dişarıdan beslenme yoluyla doğal kaynaklı antioksidan alınarak denge yeniden sağlanır ve serbest radikallerin olumsuz etkilerine karşı vücut yeniden korunmuş olur (Koca ve Karadeniz, 2005; Tawaha ve ark., 2007). Doğada antioksidan kaynağ1 olarak meyve, sebze, tahıl, bitki ve baharat gibi birçok ürün bulunmaktadır. Bu kaynakların içerisinde antioksidan bileşik olarak, fenolik asitler, flavonoidler, polifenoller, çeşitli vitaminler, tanenler ve çinko, bakır, selenyum gibi mineraller mevcuttur (Brewer, 2011; Khanduja ve Bhardwaj, 2003).

Güçlü antioksidan özelliğe sahip besinlerden biri de findıktır. Kalp dostu bir besin olarak bilinen findık yapısında yağ, karbonhidrat ve protein gibi ana bileşenlerin yanı sıra, fenolik asitler (kafeik asit, kumarik asit, ferulik asit, gallik asit, sinapik asit), flavonoidler (mirsetin, kamferol, kersetin), suda ve yağda çözünen çeşitli vitaminler (E vitamini, $\mathrm{C}$ vitamini, folik asit, tiamin, riboflavin, biotin, niasin, pridoksin, pantotenik asit) ve tanenler gibi antioksidan özellikte birçok sekonder metabolit de bulundurmaktadır. Fındığın iç çekirdeği ile birlikte çeşitli diğer kısımlarında da bu bileşiklere rastlanmaktadır (Alasalvar ve ark., 2008; Amaral ve ark., 2006; Köksal ve ark., 2006; Piccinelli ve ark., 2016). Nitekim yapılan bazı araştırmalar fındığın sert kabuk (Shahidi ve ark., 2007; Sürek ve Büyükkileci, 2018), iç zar (Piccinelli ve ark., 2016; Şahin ve ark., 2019), zuruf (yeşil yapraklı kabuk) (Alasalvar ve ark., 2006; Cerulli ve ark., 2017; Fernández-Agulló ve ark., 2012; Oğuzkan ve 
ark., 2016), yaprak (Oğuzkan ve ark., 2016; Oliveira ve ark., 2007) ve dal (Sürek ve Büyükkileci, 2018) kısımlarının da antioksidan özelliği gösterdiğini bildirmektedir.

Ülkemiz dünyada fındık üretim ve ihracatında yaklașık \% 70'lik bir oranla ilk sırada bulunmaktadır. Bu özelliği ile fındık üretimi ülke ekonomisine oldukça önemli bir katkı sağlamaktadır (Özgüven ve ark., 2020). Diğer taraftan fındık üretimi sırasında binlerce ton yan ürün açığa çıkmakta ve düşük bir ekonomik değer olarak kullanılmaktadır. Örneğin fındığın yaprak, zuruf, dal, sert kabuk gibi kısımları tarlalarda yakılmakta veya evlerde yakıt olarak kullanılmaktadır. Ayrıca fındık içinin kavrulması sırasında açığa çıkan iç zar hayvan yem sanayinde kullanılmaktadır (Çöpür ve ark., 2013; Guney, 2013; Ozyurt ve Otles, 2018; Şahin ve ark., 2019; Sürek ve Büyükkileci, 2018). Oysa bu yan ürünlerde bulunan antioksidan bileşenler geri kazanılabilir ve fitoterapötik ürünlere dönüştürülerek ekonomiye katma değer sağlanabilir. Bu çalışmanın amacı Bartın ilinde yetiştirilen findığın atık olarak kullanılan zuruf kısmının antioksidan özelliklerinin belirlenmesi ve literatürdeki findık ile ilgili yapılan diğer çalışmalarla karşılaştırılarak fındık zuruf kısmının fitoterapötik ürün olarak kullanılabilirliğinin değerlendirilmesidir.

\section{MATERYAL ve METOT}

\subsection{Deney Materyali}

Çalışmada örnek olarak Bartın bölgesinde yetişen tombul fındık (Corylus avellana L.) türü ağaçlarından toplanan fındıkların taze zuruf (yeşil yapraklı kabuk) kısımları kullanılmıştır. Fındıklar ağaçlarından hasat mevsiminden önce yeșil iken toplanmıș ve zuruf kısımları findığın kabuklu çekirdek kısmından ayrılmıştır. Ayrılan yeşil zuruflar kesici aletlerle parçalanarak ekstraksiyon işleminde kullanılmak üzere $-18{ }^{\circ} \mathrm{C}$ 'de derin dondurucuda saklanmıştır.

\subsection{Ekstraksiyon İşlemi}

Küçük parçalar haline getirilen taze findık zuruflarından 100 'er g alınarak sokslet aparatında su, aseton ve etanol çözücüleri ile 10-12 saat ayrı ayrı ekstraksiyona tabi tutulmuştur. Diğer taraftan taze zuruf parçalarından $100 \mathrm{~g}$ alınarak 250 ml'lik balon içerisine konulmuş üzerine $200 \mathrm{ml}$ su-aseton (1:1) karışımı eklenmiştir. Ara ara çalkalanmak suretiyle birkaç gün bekletilen karışım süzülüp alındıktan sonra örnek üzerine yine su-aseton (1:1) karışımı eklenerek aynı işlem üç kez tekrarlanmıştır. Elde edilen su-aseton çözeltileri en son bir araya getirilmiştir. Ekstraksiyon işlemlerinden sonra organik fazlar $40{ }^{\circ} \mathrm{C}$ 'de vakum altında evaporatörde (Buchi, Schweiz, Switzerland) uzaklaştırılmıştır. Daha sonra elde edilen tüm katı ekstreler tartılarak her biri için verim hesabı yapılmışıı.

\subsection{Antioksidan Aktivite Tayini}

\subsubsection{DPPH serbest radikal süpürücü aktivite tayini}

DPPH serbest radikal süpürücü aktivite tayini Blois (1958) yöntemine göre yapılmıştır. Tüm katı ekstreler, $250 \mu \mathrm{g} /$ $\mathrm{mL}, 500 \mu \mathrm{g} / \mathrm{mL}$ ve $1000 \mu \mathrm{g} / \mathrm{mL}$, DPPH (2,2-Difenil-1pikrilhidrazil) stok çözeltisi $6 \times 10^{-5} \mathrm{~mol} / \mathrm{L}$ konsantrasyonda olacak şekilde gerekli miktarlar tartılmış ve etanolde (\%75’lik) çözülmüştür. Her örnekten deney tüplerine, mikropipet yardımıla $300 \mu \mathrm{L}$ alınarak üzerlerine 2700 $\mu \mathrm{L}$ DPPH çözeltisi eklenmiştir. Daha sonra tüpler oda sıcaklı̆̆ında, karanlıkta 20 dakika bekletilmiştir. Süre sonunda örneklerin absorbansı $517 \mathrm{~nm}$ dalga boyunda kör olarak kullanılan etanole karşı Shimadzu UV-1800 UVVIS Spektrofotometre cihazında okunmuştur. Örneklerin DPPH serbest radikaline karşı \% inhibisyonları aşağıdaki eşitlikte verilen formüle göre hesaplanmıştır. Her örnek 3 paralel olarak çalışılmış ve sonuçlar 3 deneyden elde edilen $\%$ süpürücü etkilerinin ortalaması \pm standart hata olarak verilmiştir. Ayrıca DPPH serbest radikalinin \% 50'sini gideren konsantrasyon olan $\mathrm{IC}_{50}$ değeri de $\mu \mathrm{g} / \mathrm{ml}$ olarak verilmiştir.

$$
\% \text { İnhibisyon }=[(\mathrm{A} 1-\mathrm{A} 2) / \mathrm{A} 1] \times 100
$$

$\mathrm{A} 1=\mathrm{DPPH}$ stok çözeltisinin $517 \mathrm{~nm}$ dalga boyundaki absorbans1

A2 = Örnek çözeltilerinin $517 \mathrm{~nm}$ dalga boyundaki absorbansı

\subsubsection{ABTS katyon radikali giderim aktivite tayini}

ABTS ${ }^{+}$giderim aktivite spektrofotometrik analizi Re vd. (1999)'nin geliştirdiği metoda göre yapılmıştır. ABTS.+ katyonu, $7 \mathrm{mM}$ suda çözülmüş ABTS [2,2'-Azino-bis(3etilbenzotiazolin-6-sülfonik asit) diamonyum tuzu] ile 2,45 mM potasyum persülfatın (K2S2O8) sulu çözeltisi karıştırılıp yaklaşık 12 saat karanlıkta oda sıcaklığında bekletilerek elde edilmiştir. ABTS ${ }^{+}$çözeltisi kullanılmadan önce 734 nm'deki absorbansı $0,708 \pm 0,025$ 'ye gelene kadar 
etanolle seyreltilmiştir. Daha sonra etanolde çözülerek hazırlanan $25 \mu \mathrm{g} / \mathrm{ml}, 50 \mu \mathrm{g} / \mathrm{mL}, 100 \mu \mathrm{g} / \mathrm{mL}$ ve $200 \mu \mathrm{g} /$ $\mathrm{mL}$ konsantrasyonlardaki ekstrelerden $600 \mu \mathrm{L}$ alınarak her birinin üzerlerine $2400 \mu \mathrm{L}$ ABTS ${ }^{+}$çözeltisi eklenmiştir. Karışım 10 dakika oda sıcaklığında bekletildikten sonra 734 nm'deki absorbansları kör olarak kullanılan etanole karşı Shimadzu UV-1800 UV-VIS Spektrofotometre cihazında okutulmuştur. Her örnek 3 paralel olarak çalışılmış \% ABTS giderim aktivitesi aşağıda verilen formüle göre hesaplanmıştır. Ayrıca \% 50 radikal giderici ekstre konsantrasyonu olan $\mathrm{IC}_{50}$ değerleri $\mu \mathrm{g} / \mathrm{ml}$ olarak verilmiştir.

ABTS giderim aktivitesi $(\%)=\frac{A_{\text {kontrol }}-A_{\text {örnek }}}{A_{\text {kontrol }}} \times 100$

$\mathrm{A}_{\text {kontrol }}=$ ABTS $^{+}$çözeltisinin $734 \mathrm{~nm}$ dalga boyundaki absorbansı

$\mathrm{A}_{\text {örnek }}=$ Örnek çözeltilerin $734 \mathrm{~nm}$ dalga boyundaki absorbans1

\subsubsection{Bakır (II) indirgeme antioksidan kapasitesi tayini (CUPRAC)}

Örneklerin ekstrelerinin bakır (II) indirgeme antioksidan kapasitesi tayini Apak vd. (2004)'nin geliştirdiği CUPRAC metoduna göre yapılmıştır. Metoda göre $10 \mathrm{mM}$ suda çözülmüş $\mathrm{Cu}$ (II), 7,5 mM neokuprin çözeltisi ve $1 \mathrm{M}$ $\mathrm{pH}$ 7,0 olan amonyum asetat $\left(\mathrm{NH}_{4} \mathrm{Ac}\right)$ tamponunun her birinden test tüpüne l'er $\mathrm{mL}$ alınmış farklı konsantrasyonlarda hazırlanmış örneklerin her birinden üzerlerine toplam hacim 4,1 mL olacak şekilde eklenmiştir. Tüplerin ağzı kapatılarak 1 saat boyunca oda sıcaklığında beklenmiştir. Daha sonra karışımların $450 \mathrm{~nm}$ dalga boyunda etanole karşı absorbansları Shimadzu UV-1800 UV-VIS Spektrofotometre cihazında okunmuştur. Her örnek 3 paralel olarak çalışılmış sonuçlar absorbanlarının ortalaması \pm standart hata olarak verilmiştir. Ayrıca 0.50 absorbansa karşı ölçülen konsantrasyon olan $A_{0.50}$ değeri $\mu \mathrm{g} / \mathrm{ml}$ olarak verilmiştir.

\subsection{Toplam Fenolik Miktar Tayini}

Toplam fenolik miktarını tayin etmek için Singleton vd. (1965)'nin modifiye ettiği Folin-Ciocalteau yöntemi kullanılmıştır. Hazırlanan bitki ekstreleri $1 \mathrm{mg} / \mathrm{mL}$ olacak şekilde etanolde çözülmüştür. Sonra örnekten $20 \mu \mathrm{L}$ alınıp, üzerine sırasıyla $1580 \mu \mathrm{l}$ distile su, $100 \mu \mathrm{L}$ FolinCiocalteau reaktifi ve $300 \mu \mathrm{L} \% 20$ 'lik sodyum karbonat (Na2CO3) çözeltisi eklenmiştir. Diğer taraftan kalibrasyon eğrisini oluşturabilmek için $50 \mu \mathrm{g} / \mathrm{mL}, 100 \mu \mathrm{g} / \mathrm{mL}, 150$ $\mu \mathrm{g} / \mathrm{mL}, 250 \mu \mathrm{g} / \mathrm{mL}, \quad 500 \mu \mathrm{g} / \mathrm{mL}$ konsantrasyonlarda gallik asit dilüsyonları hazırlanmış ve örnek yerine gallik asit dilüsyonları konularak diğer çözeltiler aynen ilave edilmiştir. Tüm tüpler $40{ }^{\circ} \mathrm{C}$ 'de 30 dakika inkübasyona bırakılmıştır. Süre sonunda absorbanslar $765 \mathrm{~nm}$ dalga boyunda kör olarak kullanılan etanole karşı Shimadzu UV1800 UV-VIS Spektrofotometre cihazında ölçülmüştür. Her örnek 2 paralel olarak çalışılmıştır. Örneğin ortalama absorbansından, gallik asit kalibrasyon çözeltileri yardımıyla hazırlanan kalibrasyon eğrisine göre, toplam fenol konsantrasyonu gallik asit eşdeğeri olarak hesaplanmış ve ekstrenin toplam fenol miktarı $\mathrm{mg} / \mathrm{g}$ ekstre \pm standart hata olarak verilmiştir.

\subsection{Toplam Flavonoid Miktar Tayini}

Toplam flavonoid miktarını tayin etmek için Woisky ve Salatino (1998)'nun geliştirdiği alüminyum klorür $\left(\mathrm{AlCl}_{3}\right)$ kolorimetrik yöntemi uygulanmıştır. Hazırlanan bitki ekstreleri, konsantrasyonu $1 \mathrm{mg} / \mathrm{mL}$ olacak şekilde etanolde çözülmüştür. Daha sonra örnekten tüplere 500 $\mu \mathrm{L}$ konulmuştur. Üzerine sırasıyla $1500 \mu \mathrm{L}$ etanol, 100 $\mu \mathrm{L} \% 10$ 'luk $\mathrm{AlCl}_{3}, 100 \mu \mathrm{L} 1 \mathrm{M}$ sodyum asetat çözeltisi ve $2800 \mu \mathrm{L}$ distile su eklenmiştir. Diğer taraftan kalibrasyon eğrisini oluşturabilmek için $0,125 \mathrm{mg} / \mathrm{mL}, 0,25 \mathrm{mg} / \mathrm{mL}$, $0,50 \mathrm{mg} / \mathrm{mL}, 1,0 \mathrm{mg} / \mathrm{mL}$ konsantrasyonlarda kuersetin kalibrasyon çözeltileri hazırlanmış ve örnek yerine kuersetin dilüsyonları konularak diğer çözeltiler aynen ilave edilmiştir. Karışımlar 30 dakika oda sıcaklığında inkübasyona bırakılmıştır. Süre sonunda absorbanslar $415 \mathrm{~nm}$ dalga boyunda kör olarak kullanılan etanole karşı Shimadzu UV-1800 UV-VIS Spektrofotometre cihazında okunmuştur. Her örnek 2 paralel olarak çalışılmıştır. Örneğin ortalama absorbansından, kuersetin kalibrasyon çözeltileri yardımıyla hazırlanan kalibrasyon eğrisine göre, toplam flavonoid konsantrasyonu kuersetin eşdeğeri olarak hesaplanmış ve ekstrenin toplam flavonoid miktarı mg/g ekstre \pm standart hata olarak verilmiştir.

\section{6. İstatistik Analiz}

İstatiksel analizler, SPSS 16.0 paketi ile tek yönlü varyans analizi (ANOVA) sonrasinda Tukey Testi ile $\mathrm{p}<0.05$ önem 
derecesinde yapılmıştır. Antioksidan analizleri 3, toplam fenolik ve toplam flavonoid miktar analizleri 2 tekrar yapılarak sonuçlar ortalama değerler ve standart hata değerler ile verilmiştir.

\section{BULGULAR}

\subsection{Verim}

Fındık zurufu farklı çözücülerdeki ekstraksiyon işlemi gerçekleştirildikten sonra elde edilen ekstrenin verimi tartılarak g/100 g kuru örnek olarak hesaplanmıştır. Hesaplanan verimler Çizelge 1'de gösterilmiştir.

Çizelge 1. Fındık zuruf ekstrelerinin verimleri (g/100 g kuru örnek)

\begin{tabular}{|lc|}
\hline Ekstre & Verim $\mathbf{( g / 1 0 0 ~} \mathbf{g}$ kuru örnek $)$ \\
\hline $\mathrm{Su}$ & 26.77 \\
Su-aseton & 27.00 \\
Aseton & 17.63 \\
Etanol & 29.90 \\
\hline
\end{tabular}

Çizelge 1 incelendiğinde en yüksek verimin 29.9 g/100 g kuru örnek ile etanol ekstresinde olduğu görülmektedir. En düşük verimin ise aseton ekstresinde $(17.63 \mathrm{~g} / 100 \mathrm{~g}$ kuru örnek) olduğu tespit edilmiştir.

\subsection{DPPH Serbest Radikal Süpürüicü Aktivitesine Ait Bulgular}

Fındık zurufunun tüm ekstrelerinin DPPH serbest radikal süpürücü aktiviteleri $25 \mu \mathrm{g} / \mathrm{ml}, 50 \mu \mathrm{g} / \mathrm{ml}$ ve $100 \mu \mathrm{g} / \mathrm{ml}$ (reaksiyon ortamında) konsantrasyonlarında denenmiş ve konsantrasyon arttıkça \% aktivitenin de arttığı gözlenmiştir. Aktiviteler \% inhibisyon ve $\mathrm{IC}_{50}(\mu \mathrm{g} / \mathrm{ml})$ olarak hesaplanmış ve Çizelge 2'de verilmiştir.

Çizelge 2 incelediğinde tüm ekstrelerde $100 \mu \mathrm{g} / \mathrm{ml}$ konsantrasyonda en yüksek aktivitelerin gözlendiği saptanmıştır. $\mathrm{IC}_{50}$ değerleri karşılaştırıldığında en iyi DPPH serbest süpürücü aktivitenin su-aseton ekstresinde $(18.74 \pm 0.87 \mu \mathrm{g} / \mathrm{ml})$ olduğu, daha sonra sirayla su $(35.50 \pm 1.22 \mu \mathrm{g} / \mathrm{ml})$, etanol $(41.12 \pm 2.16 \mu \mathrm{g} / \mathrm{ml})$ ve aseton $(44.28 \pm 3.66 \mu \mathrm{g} / \mathrm{ml})$ ekstrelerinin geldiği görülmektedir. Ayrıca 1:1 oranında su-aseton karışımıyla elde edilen ekstrenin aktivitesinin yalnızca su ve yalnızca aseton ile elde edilen ekstrelerden daha yüksek olduğu tespit edilmiştir. Diğer taraftan su-aseton ekstresinin aktivitesinin $(18.74 \pm 0.87 \mu \mathrm{g} / \mathrm{ml}) \quad$ referans olarak kullanılan $\alpha$-tokoferol'ün aktivitesine $(7.31 \pm 0.17 \mu \mathrm{g} / \mathrm{ml})$ en yakın değer olduğu da belirlenmiştir.

\subsection{ABTS Katyon Radikali Giderim Aktivitesine Ait Bulgular}

Tüm ekstrelerin ABTS katyon radikal giderim aktiviteleri $5 \mu \mathrm{g} / \mathrm{ml}, 10 \mu \mathrm{g} / \mathrm{ml}, 20 \mu \mathrm{g} / \mathrm{ml}$ ve $40 \mu \mathrm{g} / \mathrm{ml}$ (reaksiyon ortamında) denenmiş, sonuçlar \% aktivite olarak ve $\mathrm{IC}_{50}$ $(\mu \mathrm{g} / \mathrm{ml})$ olarak verilmiştir (Çizelge 3.).

Çizelge 3’teki verilere bakıldığında tüm ekstrelerde konsantrasyon arttıkça \% aktivitelerin de $\operatorname{arttı̆̆} 1$

Çizelge 2. Fındık zuruf ekstrelerinin DPPH serbest radikal süpürücü aktivitesine ait bulgular

\section{DPPH Serbest Radikal Süpürücü Etki}

\begin{tabular}{lcccc}
\cline { 2 - 4 } \multicolumn{1}{c}{ Ekstre } & \multicolumn{3}{c}{$\%$ inhibisyon $\pm \mathrm{S} . \mathrm{H}^{\mathrm{a}}$} & \\
\cline { 2 - 4 } & $25 \mu \mathrm{g} / \mathrm{ml}$ & $50 \mu \mathrm{g} / \mathrm{ml}$ & $100 \mu \mathrm{g} / \mathrm{ml}$ & \\
\cline { 3 - 4 } $\mathrm{Su}$ & $40.29 \pm 2.22$ & $63.86 \pm 0.94$ & $84.86 \pm 0.99$ & \\
Su-aseton & $64.94 \pm 0.55$ & $86.98 \pm 0.75$ & $87.82 \pm 1.36$ & $35.50 \pm 1.22$ \\
Aseton & $33.68 \pm 8.74$ & $59.76 \pm 4.72$ & $83.28 \pm 3.99$ & $18.74 \pm 0.87$ \\
Etanol & $37.57 \pm 1.46$ & $59.76 \pm 0.75$ & $82.64 \pm 1.88$ & $44.28 \pm 3.66$ \\
$\alpha$-tokoferol & $*$ & $*$ & $97.45 \pm 0.91$ & $41.12 \pm 2.16$ \\
\hline
\end{tabular}

a: Standart hata $(\mathrm{n}=3)$

$\mathrm{p}<0.05$

*: Ölçüm yapılmadı 
görülmektedir. Elde edilen sonuçlar DPPH serbest radikal giderim aktivite tayinindeki sonuçlarla paralellik göstermektedir. Ekstreler $\mathrm{IC}_{50}$ değerlerine göre karşılaştırıldığında yine DPPH aktivite tayininde olduğu gibi en yüksek aktivitenin su-aseton ekstresinde
3.4. Bakır (II) İndirgeme Antioksidan Kapasitesi Tayinine (CUPRAC) Ait Bulgular

Elde edilen tüm ekstrelerin bakır (II) indirgeme antioksidan kapasiteleri farklı konsantrasyonlarda denenmiş 450 nm'deki absorbansları ve $A_{0.50}(\mu \mathrm{g} / \mathrm{ml})$ değerleri Çizelge 4'te

Çizelge 3. Fındık zuruf ekstrelerinin ABTS katyon giderim aktivitelerine ait bulgular

\section{ABTS Katyon Radikal Giderim Aktivitesi}

\begin{tabular}{|c|c|c|c|c|c|}
\hline \multirow[t]{2}{*}{ Ekstre } & \multicolumn{3}{|c|}{$\%$ aktivite \pm S.H. ${ }^{a}$} & \multirow[b]{2}{*}{$40 \mu \mathrm{g} / \mathrm{ml}$} & \multirow{2}{*}{$\mathrm{IC}_{50}(\mu \mathrm{g} / \mathrm{ml}) \pm$ S.H. ${ }^{\mathrm{a}}$} \\
\hline & $5 \mu \mathrm{g} / \mathrm{ml}$ & $10 \mu \mathrm{g} / \mathrm{ml}$ & $20 \mu \mathrm{g} / \mathrm{ml}$ & & \\
\hline $\mathrm{Su}$ & $41.49 \pm 2.87$ & $53.61 \pm 1.92$ & $73.57 \pm 1.30$ & $94.87 \pm 0.57$ & $8.06 \pm 1.12$ \\
\hline Su-aseton & $49.00 \pm 0.60$ & $67.79 \pm 1.09$ & $93.85 \pm 1.54$ & $95.48 \pm 1.00$ & $4.78 \pm 0.56$ \\
\hline Aseton & $38.83 \pm 2.38$ & $52.03 \pm 2.43$ & $69.74 \pm 2.28$ & $93.29 \pm 0.34$ & $9.78 \pm 2.15$ \\
\hline Etanol & $39.58 \pm 1.49$ & $51.89 \pm 2.40$ & $72.59 \pm 2.23$ & $94.87 \pm 0.69$ & $9.20 \pm 1.74$ \\
\hline$\alpha$-tokoferol & $*$ & $*$ & $*$ & $96.48 \pm 0.87$ & $4.31 \pm 0,10$ \\
\hline
\end{tabular}

$(4.78 \pm 0.56 \mu \mathrm{g} / \mathrm{ml})$ olduğu ortaya konmuştur. Aktivite sıralamasında su-aseton ekstresini sırasiyla su $(8.06 \pm 1.12$ $\mu \mathrm{g} / \mathrm{ml})$, etanol $(9.20 \pm 1.74 \mu \mathrm{g} / \mathrm{ml})$ ve aseton $(9.20 \pm 1.74$ $\mu \mathrm{g} / \mathrm{ml}$ ) ekstreleri takip etmektedir. Ayrıca su-aseton ekstre aktivitesinin $(4.78 \pm 0.56 \mu \mathrm{g} / \mathrm{ml})$, referans olarak kullanılan $\alpha$-tokoferol'ün aktivitesi $(4.31 \pm 0,10 \mu \mathrm{g} / \mathrm{ml})$ ile çok yakın olduğu tespit edilmiştir. verilmiştir. Ekstrelerin hepsinde konsantrasyon artışıla birlikte absorbans değerlerinde bir artış yani aktivitede artı̧̧ olduğu Çizelge 4'te görülmektedir. Diğer taraftan $\mathrm{A}_{0.50}(\mu \mathrm{g} / \mathrm{ml})$ değerleri ekstreler arasında karşılaştırıldığında en yüksek aktivitenin yine diğer antioksidan tayinlerinde olduğu gibi su-aseton ekstresinde $(8.74 \pm 2.13 \mu \mathrm{g} / \mathrm{ml})$ olduğu tespit edilmiştir. Su-aseton ekstresini sırasıyla su $(9.83 \pm 1.21 \mu \mathrm{g} / \mathrm{ml})$, aseton $(14.30 \pm 1.41 \mu \mathrm{g} / \mathrm{ml})$ ve etanol

Çizelge 4. Fındık zuruf ekstrelerinin bakır (II) indirgeme antioksidan kapasitesi tayinine ait bulgular

\section{Bakır (II) indirgeme antioksidan kapasitesi}

Ekstre

\begin{tabular}{lc}
\cline { 2 - 2 } & $31.25 \mu \mathrm{g} / \mathrm{ml}$ \\
\hline $\mathrm{Su}$ & $0.658 \pm 0.03$ \\
Su-aseton & $0.972 \pm 0.06$ \\
Aseton & $0.610 \pm 0.05$ \\
Etanol & $0.564 \pm 0.08$ \\
$\alpha$-tokoferol & $*$ \\
\hline
\end{tabular}

a: Standart hata $(\mathrm{n}=3)$

$\mathrm{p}<0.05$

*: Ölçüm yapılmadı
(450 nm'deki absorbans \pm S. $\mathrm{H}^{\mathrm{a}}$ )

\begin{tabular}{ccc}
$62.5 \mu \mathrm{g} / \mathrm{ml}$ & $125 \mu \mathrm{g} / \mathrm{ml}$ & $250 \mu \mathrm{g} / \mathrm{ml}$ \\
\cline { 2 - 3 } $1.258 \pm 0.03$ & $2.297 \pm 0.06$ & $3.740 \pm 0.03$ \\
$1.878 \pm 0.03$ & $3.238 \pm 0.12$ & $4.000 \pm 0.00$ \\
$1.144 \pm 0.06$ & $2.000 \pm 0.08$ & $3.391 \pm 0.04$ \\
$1.088 \pm 0.05$ & $1.930 \pm 0.04$ & $3.352 \pm 0.01$ \\
$*$ & $*$ & $2.220 \pm 0.01$
\end{tabular}

$\mathrm{A}_{0.50}(\mu \mathrm{g} / \mathrm{ml}) \pm \mathrm{S} . \mathrm{H} .^{\mathrm{a}}$

$9.83 \pm 1.21$

$8.74 \pm 2.13$

$14.30 \pm 1.41$

$18.96 \pm 0.65$

$0.54 \pm 0.01$ 
$(18.96 \pm 0.65 \mu \mathrm{g} / \mathrm{ml})$ ekstreleri takip etmektedir.

\subsection{Toplam Fenolik ve Flavonoid Miktar Tayinine Ait Bulgular}

Ekstrelere ait toplam fenolik miktar tayinleri gallik asit eşdeğeri olarak, flavonoid miktar tayinleri kuersetin eşdeğer olarak hesaplanmış ve değerler $\mathrm{mg} / \mathrm{g}$ ekstre olarak verilmiştir (Çizelge 5).

Çizelge 5'teki veriler incelendiğinde su-aseton ekstresinin $(273.56 \pm 10.12 \mathrm{mg} / \mathrm{g})$ toplam fenolik miktarı en yüksek olarak görülmektedir. Su-aseton ekstresini sırasıyla su $(257.69 \pm 46.99 \mathrm{mg} / \mathrm{g})$, etanol $(189.67 \pm 5.46 \mathrm{mg} / \mathrm{g})$ ve aseton $(172.49 \pm 17.48 \mathrm{mg} / \mathrm{g})$ ekstreleri takip etmektedir. Diğer taraftan toplam flavonoid miktarları karşılaştıııldığında toplam fenolik miktarlarından farklı bir sonuç ortaya çımakta ve en yüksek miktarın su ekstresinde $(10.61 \pm 3.96$ $\mathrm{mg} / \mathrm{g}$ ) olduğu dikkati çekmektedir.

\section{TARTIŞMA VE SONUÇ}

Çalışmadan elde edilen tüm veriler incelendiğinde fındık zurufundaki toplam fenolik miktarı ile antioksidan aktiviteleri arasında bir bağlantı olduğu dikkati çekmektedir (Çizelge 6).

Çizelge 6 incelendiğinde toplam fenolik madde miktarı ile tüm antioksidan aktivitelerinde paralellik olduğu görülmektedir. Tüm ekstreler karşılaştırıldığında toplam fenolik madde miktarı en yüksek olan su-aseton ekstresi çıarken, diğer taraftan DPPH serbest radikal süpürücü etki, ABTS katyon radikal giderim aktivitesi ve bakır (II) indirgeme antioksidan kapasitesi tayinlerinin tümünde yine su-aseton ekstresinin en yüksek aktiviteyi gösterdiği tespit edilmiştir. Diğer ekstrelere bakıldığında da toplam fenolik miktarı düşük olan ekstrenin antioksidan aktivitelerinin daha düşük olduğu göze çarpmaktadır. Buradan yola çıkarak ekstrelerin antioksidan kapasitelerinin, içerdikleri

Çizelge 5. Findık zuruf ekstrelerinin toplam fenolik ve flavonoid miktar tayinlerine ait bulgular

Ekstre

$\begin{array}{llr}\text { Su } & & 257.69 \\ \text { Su-aseton } & & 273.56 \\ \text { Aseton } & 172.49 \\ \text { Etanol } & & 189.67 \\ & & \\ & \text { a: } \mathrm{mg} / \mathrm{g} \text { ekstre Gallik asit eşdeğeri } \\ & \text { b: } \mathrm{mg} / \mathrm{g} \text { ekstre Kurtsetin eşdeğeri } \\ & \text { c: Standart hata }(\mathrm{n}=2) \\ & \mathrm{p}<0.05\end{array}$

Toplam Flavonoid Miktar $\left(\mathrm{mg} / \mathrm{g}^{\mathrm{b}} \pm \mathrm{S} . \mathrm{H}^{\mathrm{c}}\right)$

Çizelge 6. Fındık zuruf ekstrelerinin toplam fenolik miktar ve antioksidan aktivitelerinin karşılaştırılması

\begin{tabular}{|c|c|c|c|c|}
\hline Ekstre & $\begin{array}{c}\text { Toplam Fenolik } \\
\text { Miktar } \quad\left(\mathrm{mg} / \mathrm{g}^{\mathrm{a}} \pm\right. \\
\left.\text { S.H } \mathrm{H}^{\mathrm{b}}\right)\end{array}$ & $\begin{array}{l}\text { DPPH Serbest Radikal } \\
\text { Süpürücü Etki } \\
\mathrm{IC}_{50}(\mu \mathrm{g} / \mathrm{ml}) \pm \mathrm{S} . \mathrm{H} .{ }^{\mathrm{b}}\end{array}$ & $\begin{array}{c}\text { ABTS Katyon Radikal } \\
\text { Giderim Aktivitesi } \\
\mathrm{IC}_{50}(\mu \mathrm{g} / \mathrm{ml}) \pm \text { S.H. }{ }^{\mathrm{b}}\end{array}$ & $\begin{array}{l}\text { Bakır (II) indirgeme } \\
\text { antioksidan kapasitesi } \\
\mathrm{A}_{0.50}(\mu \mathrm{g} / \mathrm{ml}) \pm \mathrm{S} . \mathrm{H} .^{\mathrm{b}}\end{array}$ \\
\hline $\mathrm{Su}$ & $257.69 \pm 46.99$ & $35.50 \pm 1.22$ & $8.06 \pm 1.12$ & $9.83 \pm 1.21$ \\
\hline Su-aseton & $273.56 \pm 10.12$ & $18.74 \pm 0.87$ & $\mathbf{4 . 7 8} \pm 0.56$ & $\mathbf{8 . 7 4} \pm 2.13$ \\
\hline Aseton & $172.49 \pm 17.48$ & $44.28 \pm 3.66$ & $9.78 \pm 2.15$ & $14.30 \pm 1.41$ \\
\hline Etanol & $189.67 \pm 5.46$ & $41.12 \pm 2.16$ & $9.20 \pm 1.74$ & $18.96 \pm 0.65$ \\
\hline
\end{tabular}

a: $\mathrm{mg} / \mathrm{g}$ ekstre Gallik asit eşdeğeri

b: Standart hata 
toplam fenolik miktara bağlı olduğu söylenebilmektedir. Diğer taraftan ekstrelerde en yüksek verim etanol ekstresinde görülürken toplam fenolik madde miktarı ise su-aseton ekstresinde belirlenmiştir. Bu farklılı̆̆ın nedeni olarak etanol ekstresi içerisinde fenolik bileşenler dışında çözünmüş başka bileşiklerin de bulunduğu söylenebilir.

Yapılan bu çalışmada literatürde pek karşılaşılmayan findığın zuruf kısmı kullanılmıştır. Fındık ağacının besin olarak kullanılan çekirdek kısmının antioksidan özelliği ile ilgili birçok çalışma mevcuttur. Fakat yaprak (Oğuzkan ve ark., 2016; Oliveira ve ark., 2007; Shahidi ve ark., 2007), dış kabuk (Shahidi ve ark., 2007; Sürek ve Büyükkileci, 2018), iç zar (Piccinelli ve ark., 2016; Şahin ve ark., 2019; Shahidi ve ark., 2007), dal (Sürek ve Büyükkileci, 2018) ve zuruf (Alasalvar ve ark., 2006; Cerulli ve ark., 2017; Fernández-Agulló ve ark., 2012; Oğuzkan ve ark., 2016; Shahidi ve ark., 2007; Sürek ve Büyükkileci, 2018) gibi yan ürün olan kısımları ile ilgili antioksidan çalışmaları sınırlıdır. Alasalvar ve ark. (2006) yaptığı bir çalışmada Giresun tombul findığının zuruf kısmını güneşte kurutarak etanol-su (80:20) ve aseton-su (80:20) karışımlarında ekstraksiyonunu gerçekleştirmişler ve elde edilen ekstrelerin toplam fenolik ve DPPH serbest radikal giderici aktivitelerine bakmışlardır. Toplam fenolik miktarları etanol-su ve asseton-su ekstresilerinde sırasıyla $156 \pm 1.0$ ve $201 \pm 2.0 \mathrm{mg}$ kateşin eşdeğer/ g ekstre olarak hesaplanmıştır. DPPH serbest radikal süpürücü aktiviteleri ise IC50 olarak hesaplanmış etanol-su ve asseton-su ekstresilerinde sirasiyla $0.074 \pm 0.002$ ve 0.065 $\pm 0.002 \mathrm{mg} / \mathrm{ml}$ olarak tespit edilmiştir. Fındik zurufu ile yapılan bir diğer çalışmada Fernández-Agulló ve ark. (2012) fındık zurufunu kurutarak farklı çözücülerdeki ekstrelerinin toplam fenolik miktar, DPPH, ABTS ve FRAP demir indirgeme antioksidan kapasitesi aktivitelerini incelemişlerdir. Elde edilen sonuçlarda en yüksek toplam fenolik miktar $13.43 \pm 0.20 \mathrm{~g}$ Gallik asit eşdeğer/ $100 \mathrm{~g}$ ekstre ile etanol-su (1:1) ekstresinde bulunmuştur. En yüksek DPPH $(0.155 \pm 0.002 \mathrm{mg} / \mathrm{ml})$ ve ABTS $(0.988 \pm$ $0.008 \mathrm{mg} / \mathrm{ml}$ ) aktivitelerinin yine aynı ekstrede olduğunu tespit etmişlerdir. Oğuzkan ve ark. (2016) ise yaptıkları çalışmada findık zurufunun metanol ekstresinin DPPH serbest radikal süpürücü aktivitesine bakmışlar ve sonucu IC50 cinsinden $3.42 \mu \mathrm{g} / \mathrm{ml}$ olarak bulmuşlardır. Shahidi ve ark. (2007) findık zurufunun etanol-su (80:20) ekstresi ile yaptıkları çalışmada toplam fenolik miktar $127.3 \pm 0.7 \mathrm{mg}$ kateşin eşdeğer/ g ekstre, DPPH aktivitesi ise 50 ppm'de \% $97.3 \pm 0.1,100$ ppm'de $\% 99.5 \pm 0.1$ olarak belirlenmiştir. Çalışmada Bartın ilinde yetiştirilen tombul fındık türü kullanılmıştır. Yapılan diğer çalışmalardan farklı olarak findığın zurufu taze yeşil olarak toplanıp kurutulmadan kullanılmıştır. Ayrıca çalışmada findık zurufunun dört farklı ekstresi (su, su-aseton, aseton, etanol) ile üç farklı antioksidan aktivite tayini (DPPH, ABTS, CUPRAC) yapılmıştır. Tüm ekstrelerin toplam fenolik miktar tayininin yanında toplam flavonoid miktar tayini de çalışılmıştır. Elde ettiğimiz toplam fenolik miktar, DPPH ve ABTS aktivite sonuçlarına bakıldığında özellikle suaseton ekstresinin sonuçlarının literatürde yapılan diğer çalışmalardaki sonuçlarla karşılaştırıldığında oldukça yüksek olduğu söylenebilir. Bu çalışma ile fındığın zuruf kısmının da antioksidan özelliğinin yüksek olduğu fındık ağacının besin olarak kullanılan çekirdek kısmıyla birlikte atık olarak görülen bu kısmının da farklı alanlarda değerlendirilebileceği görülmüştür. Diğer taraftan zurufun yüksek antioksidan özelliğe sahip olması, yapılacak diğer biyolojik çalışmalara ışık tutmaktadır.

\section{KAYNAKLAR}

Alasalvar, C., Hoffman, A., ve Shahidi, F. (2008). Antioxidant Activities and Phytochemicals in Hazelnut (Corylus avellana L.) and Hazelnut ByProducts. In Tree Nuts: Composition, Phytochemicals, and Health Effects (Issue December, pp. 217-235). CRC Press.

Alasalvar, C., Karamać, M., Amarowicz, R., ve Shahidi, F. (2006). Antioxidant and antiradical activities in extracts of hazelnut kernel (Corylus avellana L.) and hazelnut green leafy cover. Journal of Agricultural and Food Chemistry, 54(13), 4826-4832.

Amaral, J. S., Casal, S., Citová, I., Santos, A., Seabra, R. M., ve Oliveira, B. P. P. (2006). Characterization of several hazelnut (Corylus avellana L.) cultivars based in chemical, fatty acid and sterol composition. European Food Research and Technology, 222, 274280.

Brewer, M. S. (2011). Natural Antioxidants: Sources, Compounds, Mechanisms of Action, and Potential Applications. Comprehensive Reviews in Food Science and Food Safety, 10(4), 221-247. 
Cerulli, A., Lauro, G., Masullo, M., Cantone, V., Olas, B., Kontek, B., Nazzaro, F., Bifulco, G., ve Piacente, S. (2017). Cyclic Diarylheptanoids from Corylus avellana Green Leafy Covers: Determination of Their Absolute Configurations and Evaluation of Their Antioxidant and Antimicrobial Activities. Journal of Natural Products, 80(6), 1703-1713.

Çöpür, Y., Tozluoglu, A., ve Özkan, M. (2013). Evaluating pretreatment techniques for converting hazelnut husks to bioethanol. Bioresource Technology, 129, 182-190.

Cornelli, U. (2009). Antioxidant use in nutraceuticals. Clinics in Dermatology, 27(2), 175-194.

Fernández-Agulló, A., Gómez-Castro, C., Soto, L., Freire, M. S., ve González-Álvarez, J. (2012). Study of the antioxidant potential of forestry biomass waste. WIT Transactions on Ecology and the Environment, 163, 323-334.

Guney, M. S. (2013). Utilization of hazelnut husk as biomass. Sustainable Energy Technologies and Assessments, 4, 72-77.

Khanduja, K. L., ve Bhardwaj, A. (2003). Stable free radical scavenging and antiperoxidative properties of resveratrol compared in vitro with some other bioflavonoids. Indian Journal of Biochemistry and Biophysics, 40(6), 416-422.

Koca, N., ve Karadeniz, F. (2005). Gıdalardaki doğal antioksidan bileşikler. Gıda Dergisi 30(4), 229-236.

Köksal, A. I., Artik, N., Şimşek, A., ve Güneş, N. (2006). Nutrient composition of hazelnut (Corylus avellana L.) varieties cultivated in Turkey. Food Chemistry, 99(3), 509-515.

Matsingou, T. C., Kapsokefalou, M., ve Salifoglou, A. (2000). In vitro antioxidant activity of Black Tea and Mediterranean herb infusions toward iron under stimulated gastrointestinal conditions. Journal of Food Science, 65(6), 1060-1065.

Oğuzkan, S. B., Uğraş, S., Can, M., Uzun, A., Ülger, S., ve Üzmez, Ş. (2016). Fındık (Corylus avellana L.) Yeşil Kabuk ve Yaprak Ekstraklarında Biyolojik Aktivite Tayini. Kahramanmaraş Sütçü Imam Üniversitesi Doğa Bilimleri Dergisi, 19(4), 373-378.

Oliveira, I., Sousa, A., Valentão, P., Andrade, P. B., Ferreira, I. C. F. R., Ferreres, F., Bento, A., Seabra, R., Estevinho, L., ve Pereira, J. A. (2007). Hazel (Corylus avellana L.) leaves as source of antimicrobial and antioxidative compounds. Food Chemistry, 105(3), 1018-1025.

Özgüven, M., Beyde, B., ve Özçelik, B. (2020). Atıkların Değerlendirmesi: Fındık (Corylus avellana L.) ve Antep Fıstığı (Pistacia vera L.) İç Zarlarından Elde Edilen Fenolikçe Zengin Ekstraktlara Lipozomal Taşıma Sistemlerinin Uygulanabilirliği. European Journal of Science and Technology, 19, 241-246.

Ozyurt, V. H., ve Otles, S. (2018). Hazelnut testa as a by-product: Nutritional composition, antioxidant activity, phenolic compound profile and dietary fiber content. Ankara Universitesi Eczacilik Fakultesi Dergisi, 42(3), 38-57.

Piccinelli, A. L., Pagano, I., Esposito, T., Mencherini, T., Porta, A., Petrone, A. M., Gazzerro, P., Picerno, P., Sansone, F., Rastrelli, L., ve Aquino, R. P. (2016). HRMS Profile of a Hazelnut Skin Proanthocyanidinrich Fraction with Antioxidant and Anti-Candida albicans Activities. Journal of Agricultural and Food Chemistry, 64(3), 585-595.

Şahin, S., Kiliç, Ö., Şengül, S., ve Perçİn, S. (2019). Farklı İllerden Temin Edilen Fındık Zarının Bileşimi ve Antioksidan Etkinliğinin Araştırılması. Ordu Üniversitesi Bilim ve Teknoloji Dergisi, 9(1), 27-35.

Shahidi, F., Alasalvar, C., Liyana-Pathirana, ve M., C. (2007). Antioxidant phytochemicals in hazelnut kernel (Corylus avellana L) and hazelnut byproducts. Journal of Agricultural and Food Chemistry, 55(4), 1212-1220.

Sürek, E., ve Büyükkileci, A. O. (2018). Extraction of Antioxidant Compounds From Hazelnut Wastes Using Subcritical Water. The Journal of Food, 43(2), 211-221.

Tawaha, K., Alali, F. Q., Gharaibeh, M., Mohammad, M., ve El-Elimat, T. (2007). Antioxidant activity and total phenolic content of selected Jordanian plant species. Food Chemistry, 104(4), 1372-1378.

Yılmaz, İ. (2010). Antioksidan İçeren Bazı Gıdalar ve Oksidatif Stres. Inönü Üniversitesi T⿰p Fakültesi Dergisi, 17(2), 143-153. 